\title{
Geographic variation in skull shape of the water rat Scapteromys tumidus (Cricetidae, Sigmodontinae): isolation-by-distance plus environmental and geographic barrier effects?
}

\author{
FERNANDO M. QUINTELA ${ }^{1}$, RODRIGO FORNEL ${ }^{2}$ and THALES R.O. FREITAS ${ }^{1,3}$ \\ ${ }^{1}$ Programa de Pós-Graduação em Biologia Animal, Departamento de Zoologia, Instituto de Biociências, Universidade Federal \\ do Rio Grande do Sul (UFRGS), Avenida Bento Gonçalves, 9500, Prédio 43435, 91501-970 Porto Alegre, RS, Brasil \\ ${ }^{2}$ Programa de Pós-Graduação em Ecologia, Departamento de Ciências Biológicas, Universidade Regional Integrada do \\ Alto Uruguai e das Missões, Campus de Erechim, Avenida Sete de Setembro, 1621, 99700-000 Erechim, RS, Brasil \\ ${ }^{3}$ Departamento de Genética, Instituto de Biociências, Universidade Federal do Rio Grande do Sul \\ (UFRGS), Avenida Bento Gonçalves, 9500, Prédio 43323, 91501-970 Porto Alegre, RS, Brasil
}

Manuscript received on December 5, 2014; accepted for publication on January 30, 2015

\begin{abstract}
The geographic variation in skull size and shape of the swamp rat Scapteromys tumidus was examined in samples from eight geographic clusters in almost of its distribution in southern Brazil and Uruguay. For analysis we used two-dimensional geometric morphometric methods for dorsal, ventral and lateral views of the skull. The geometric descriptors showed no significant differences in skull size between geographic clusters, while differences in shape were highly significant. We found a significant and moderate correlation between geographic and morphological distances, corroborating the isolation-by-distance model. Samples from the Rio Grande do Sul central coastal plain were the most differentiated, segregating completely from all other samples in canonical variate analysis for the dorsal view. The most visible variable regions in skull were the zygomatic arch (mainly the squamosal root of zygomatic) and the lateral braincase borders. Once correlation between geographic and morphological distances were not strong, it is possible that other factors (environmental heterogeneity and/or geographic barriers) may are acting in S. tumidus skull differentiation.
\end{abstract}

Key words: Akodontini, isolation-by-distance, geometric morphometrics, skull morphology, Pampa.

\section{INTRODUCTION}

Microevolution is a process of small evolutionary changes within populations of a determined species (Avise 2000). Such changes in genetic and morphological characters within and among populations characterize different evolutionary units over geographic space (dos Reis et al. 2002a).

Correspondence to: Fernando Marques Quintela

E-mail: fmquintela@yahoo.com.br
In relation to morphological traits, intraspecific variations occur as a result of genetic diversity, selection, reproductive isolation and other factors. Microevolutionary events, however, are the driving force of macroevolution (evolution beyond species level) processes, resulting in speciation (Avise 2000).

Intraspecific morphological variation can be accessed by using methods of traditional and geometric morphometric analysis (Rohlf and 
Marcus 1993, Fruciano et al. 2011). The traditional or multivariate methods are based on analysis of distances (i.e. lengths and widths), angles and ratios, while the geometric morphometrics techniques capture the shape of structures in two-dimensional (2-D) or three-dimensional (3-D) coordinates of landmark points (Rohlf and Marcus 1993, Adams et al. 2004). Therefore, geometric morphometrics represents an advance over traditional methods, since visualization of shape variation is possible through graphic representations (Rohlf and Marcus 1993, Monteiro and dos Reis 1999). In addition, morphometric geometrics also deals with the size factor by the properties of the centroid size (Bookstein 1991), a vector independent from shape (Monteiro and dos Reis 1999).

The detection and description of geographic variation on skull size and shape are important for investigations on mammalian systematics and taxonomy (Barčiová 2009, Yazdi 2011). In relation to rodents, geographically based studies have addressed closely related species (i.e. Fadda and Corti 1998, 2000, 2001, Beolchini and Corti 2004, Mullin et al. 2004a, b, Barčiová and Macholán 2006) or variations within single species (dos Reis et al. 2002a, Fornel et al. 2010, Yazdi et al. 2011). In the latter cases, distinct morphological geographic units were revealed, concording with the isolation-by-distance model, in which an increase on geographic distance results in a decrease of gene flow, increase of genetic divergence and consequently higher morphological differentiation (Wright 1943).

The genus Scapteromys comprises three recognized species of sigmodontine cricetid rodents, inhabitants of riverine and palustrine systems (Quintela et al. 2014). Scapteromys aquaticus (Thomas, 1920) is a $2 n=32$ karyomorph (Brum-Zorrilla et al. 1986) that extends from southern Paraguay to east-central Argentina, with individual records in Las Cañas, southeastern Uruguay, and São Borja, west of the state of Rio Grande do Sul, southern Brazil (Bonvicino et al.
2013). Scapteromys tumidus (Waterhouse, 1837) has a karyotype of $2 n=24$ and occurs in Uruguay and Rio Grande do Sul (Brum-Zorrilla et al. 1972, Freitas et al. 1984, Brum-Zorrilla et al. 1986, D’Elía and Pardiñas 2004, Musser and Carleton 2005). Scapteromys meridionalis (Quintela et al. 2014) $(2 n=34-36)$ was recently described and inhabits palustrine systems in the Araucaria Forest (Mixed Ombrophilous Forest) domains of northern Rio Grande do Sul, Santa Catarina and Paraná states.

The morphological traits of Scapteromys have been researched, which resulted in taxonomic and systematic reevaluations. Gyldenstolpe (1932) redescribed the genus, providing new morphological observations and listing five species ( $S$. aquaticus, $S$. fronto, $S$. gnambiquarae, S. tomentosus, and S. tumidus). Ellerman (1941) provided generic external and craniodental anatomical definitions and listed the five named forms recognized by Gyldenstolpe (1932). Massoia and Fornes (1964) compared qualitative (coat color, fronto-parietal suture and mesopteygoid fossa shape) and quantitative (external, cranial, penile and bacular) characters between Argentinean and Uruguayan samples, assuming a subespecific classification for (S. t. tumidus for Uruguay and S. t. aquaticus for Argentina). Hershkovitz (1966) presented external, craniodental, penile and bacular anatomical descriptions and some external, cranial and bacular measures of S. tumidus, and considered the Argentinean and Uruguayan forms as distinct species. A significant contribution to the systematics of Scapteromys was made by D'Elía and Pardiñas (2004), who analyzed 564 skulls from 68 populations in Paraguay, Argentina and Uruguay. Working with qualitative traits and craniodental morphometrics, in addition to mitochondrial DNA, these authors reinforced the existence of two clades at a specific level, finding $S$. aquaticus in Paraguay and Argentina plus one locality in western Uruguay, and $S$. tumidus in Uruguay. Despite the efforts already undertaken, Scapteromys lacks complete descriptive and integrative information, seeing 
that none of these studies properly analyzed the Brazilian populations.

The aim of this study was to investigate variation in skull shape and size of Scapteromys tumidus among populations sampled over most of the species distribution. Therefore, we performed statistical analysis of data generated by 2-D geometric morphometrics. We tested the correlation between geographic distance and morphological differentiation. This information was used to test the isolation-by-distance hypothesis, which might affect skull morphological traits in Scapetomys.

\section{MATERIALS AND METHODS}

\section{SAMPLE}

Specimens of $S$. tumidus from nine localities in Rio Grande do Sul were collected from March
2003 through October 2011. Specimens from three additional localities in Rio Grande do Sul were obtained from the Museu de Ciências Naturais of Universidade Luterana do Brasil (MCNU), Canoas, Brazil. Specimens from seven localities in Uruguay and one locality in Rio Grande do Sul were photographed at American Museum of Natural History (AMNH), New York, United States. Sample sizes are given in Appendix I and sampled localities are shown in Figure 1. The material examined consisted of 180 specimens (107 males and 73 females) for the dorsal view, 172 specimens (102 males and 70 females) for the ventral view and 167 specimens (101 males and 66 females) for the lateral view. All of the specimens were adults according to Barlow (1969), with the third molar fully erupted and showing signs of wear.

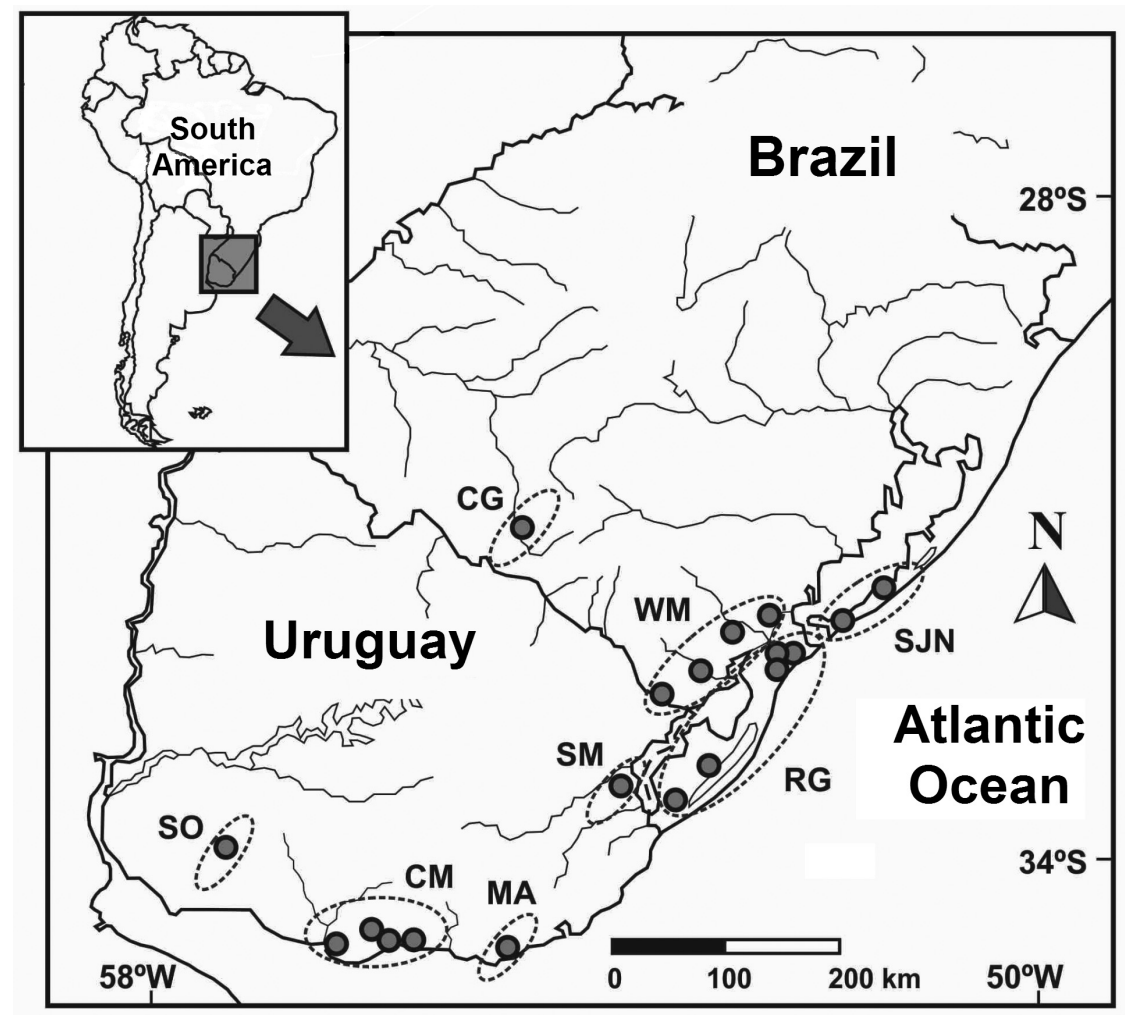

Figure 1 - Map with locations of Scapteromys tumidus sampled populations and geographic clusters in southern Brazil and Uruguay. Information on voucher specimens are listed in Appendix I. 


\section{GEOMETRIC MORPHOMETRICS}

Undamaged skulls were photographed in the dorsal, ventral and left lateral views. Damaged skulls were photographed only in the view(s) with the landmark regions intact. The photographs were taken with a digital camera with 10 megapixels $(4608 \times 3456)$ of resolution, zoom of $2.1 \times$ and external accessory illumination. Camera lens was positioned parallel to the photographic background, by means of an adjustable support platform. Millimeter graph paper was used as a photographic background, aiding in skull alignment and subsequent scale referencing. For photographs of the dorsal and ventral views, the skulls were positioned on the background with modeling clay and the molars surface were aligned with the background with the aid of a set-square. For the photographs of the lateral view, skulls were fixed on the background by the zygomatic arch and the molar surfaces were aligned with the horizontal lines of the millimeter paper. Twentytwo two-dimensional landmarks were collected in the dorsal view, 23 in the ventral view and 22 in the lateral view of the skull (Fig. 2, Appendix II). Coordinates of landmarks were obtained using the software TPSDig2, version 2.16 (Rohlf 2010). Coordinates were superimposed using a generalized Procrustes analysis (GPA) algorithm (Dryden and Mardia 1998), which removed the effects of scale, orientation and position differences (Rohlf and Marcus 1993). The size of each skull in each view was estimated from its centroid size, which is defined as the square root of the sum of the squares of the distances of each landmark from the centroid (Bookstein 1991). Because we used different distances in skull photographs, a size correction was made by IMP CoordGen6f (Sheets 2001), using a scale factor.

SIZE

The sexual dimorphism was evaluated using two groups, formed by the set of male or female
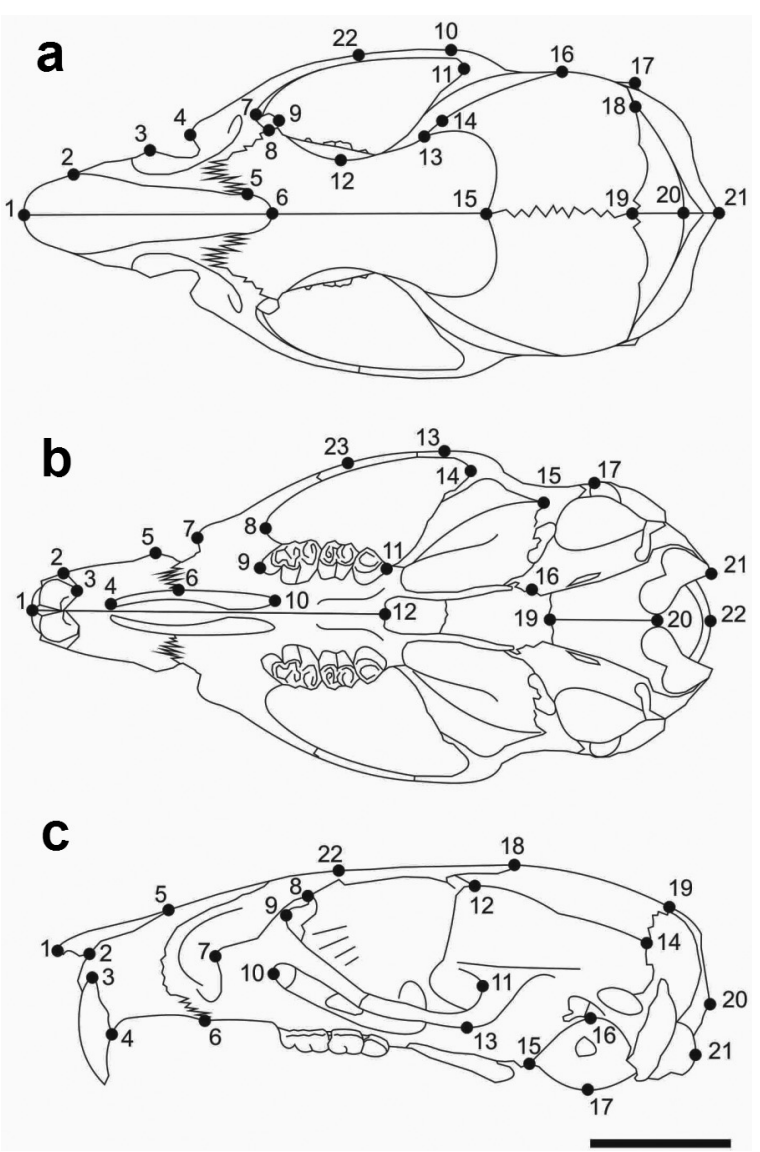

Figure 2 - Landmark locations on dorsal (a), ventral (b) and lateral (c) views of skull of Scapteromys tumidus. Detailed description of the location of landmarks is given in Appendix II.

specimens of all populations. Size differences between sexes for each view were tested with a Student's $t$-test on log-transformed centroid size. The ANOVAs were used to compare the $\log$ centroid size for geographic clusters, and for multiple comparisons we used Tukey's test.

SHAPE

The difference in shape between sexes for each view was tested with a multivariate analysis of variance (MANOVA) on shape variables. In order to improve the multivariate analyses and graphic visualization, neighboring localities without a potential barrier to gene flow (large rivers, lagoons and estuary mouths) were grouped in 8 geographic clusters, named: Campanha Gaúcha (CG), West 
margin of Mirim lagoon (WM), São José do Norte restinga $(\mathrm{SJN})$, Rio Grande restinga $(\mathrm{RG})$, Soriano (SO), Maldonado (MA), South of Mirim lagoon (SM), Canelones/Montevideo (CM) (Fig. 1). Because the MANOVA did not detect significant differences in shape, and only detected small significant differences in size for the dorsal view between sexes (see results), males and females were pooled for analysis of the geographic variation. A consensus configuration of landmark configurations of all clusters was computed for the dorsal, ventral and lateral views, based on the orthogonal generalized least-squares Procrustes method (Rohlf and Slice 1990). The hypothesis of the existence of significant differences in skull shape among geographic clusters was tested with the MANOVA method for each view. Next, we performed a pairwise MANOVA, aiming to identify the pairs of clusters that showed significant differences in shape. We performed a linear discriminant analysis (LDA), calculated on a subset of PC's to compute the leave-one-out cross-validation to calculate the percentages of the correct classification for each clusters defined a priori (Baylac and Friess 2005). We performed a Canonical Variate Analysis (CVA) as a discriminant analysis, with all clusters pooled and the distribution of clusters visualized in the multivariate space of the first two canonical axes. The adequacy of the isolation-by-distance model for our data was examined by two tests. The first uses morphometric data to calculate the Mahalanobis distance matrix (morphological distances) between pairwise clusters. The morphological similarities and dissimilarities between clusters were visualized in a phenogram resulting from the Neighbor-joining method, using Mahalanobis distances for each view. The second is a Mantel test, which analyzed the correlation between the two matrices, geographic distances and Mahalanobis morphological distances, using 10000 random permutations. The geographic distance matrix was based on linear distances of each locality constructed by the software Geographic Distance
Matrix Generator, version 1.2.3 (Ersts 2009). For the statistical analyses and to generate graphs, we used the " $\mathrm{R}$ " language for statistical computing, version 2.14.1 (R Development Core Team; http:// www.r-project.org) and the libraries "ape" (Paradis et al. 2004), "ade4" (Dray and Dufour 2007), "MASS" (Venables and Ripley 2002), and "stats" (R Development Core Team). For geometric morphometrics, the procedures were carried out using the "Rmorph" library for R (Baylac 2008).

\section{RESULTS}

SEXUAL DIMORPHISM

The Student's $t$-test showed significant differences in centroid size between the sexes for the dorsal view $(\mathrm{t}=-2.172$, d.f. $=1, P=0.031)$, while the differences were not significant for the ventral $(\mathrm{t}=$ -0.1753 , d.f. $=1, P=0.082)$ and lateral $(\mathrm{t}=-1.205$, d.f. $=1, P=0.23)$ views.

The results of MANOVA showed no significant differences in shape between males and females for any view (dorsal: $\lambda_{\text {Wilks }}=0.735 ; F_{(1,178)}=1.101 ; P$ $=0.330 ;$ ventral: $\lambda_{\text {Wilks }}=0.675 ; F_{(1,170)}=1.306 ; P$ $=0.124$; lateral: $\lambda_{\text {Wilks }}=0.706 ; F_{(1,165)}=1.306 ; P=$ $0.272)$.

\section{GEOGRAPHIC VARIATION IN SIZE AND SHAPE}

The results of ANOVA showed no significant differences in centroid size among geographic clusters (dorsal: $F_{(7,172)}=1.583 ; P=0.143$; ventral: $F_{(7,164)}=1.79 ; P=0.092$; lateral: $F_{(7,159)}=1.362 ; P$ $=0.225)$.

The MANOVA tests detected significant differences in skull shape among geographic clusters for all views (dorsal: $\lambda_{\text {wilks }}=0.0044 ; F_{(7,172)}$ $=3.482 ; P=2.2 \times 10^{-16}$; ventral: $\lambda_{\text {Wilks }}=0.0063 ; F_{07}$, ${ }_{164)}=2.793 ; P=2.2 \times 10^{-16}$; lateral: $\lambda_{\text {Wilks }}=0.0053$; $\left.F_{(7,159)}=2.988 ; P=2.2 \times 10^{-16}\right)$. The pairwise MANOVA showed significant differences in 22 of 28 comparisons between geographic clusters. The $F$ values and significance levels are shown in Table I. 
TABLE I

F values and significance levels of pairwise MANOVA analysis of variation in Scapteromys tumidus skull shape among eight geographic clusters in southern Brazil and Uruguay, for dorsal, ventral and lateral views $(* P<0.05 ; * * P<0.01 ; * * * P<0.001)$.

\begin{tabular}{|c|c|c|c|c|c|c|c|}
\hline \multicolumn{8}{|c|}{ Dorsal view } \\
\hline & WM & SJN & RG & CG & SO & MA & SM \\
\hline SJN & $10.2 * * *$ & & & & & & \\
\hline RG & 1.6 & $6.6 * * *$ & & & & & \\
\hline CG & 2.0 & $24.8 * * *$ & $3.1 * *$ & & & & \\
\hline SO & $4.4^{* *}$ & $22.3^{* * *}$ & $4.0^{* * *}$ & $8.6^{* * *}$ & & & \\
\hline MA & $24.9 * * *$ & $16.1 * * *$ & $4.5^{* * *}$ & $17.2^{* * *}$ & $19.8^{* * *}$ & & \\
\hline SM & $3.9^{*}$ & $15.7 * * *$ & $2.6^{*}$ & 4.2 & $6.4^{* *}$ & 4.9 & \\
\hline $\mathrm{CM}$ & 2.9 & $12.7 * * *$ & $2.9 * *$ & $4.1^{*}$ & $5.5^{*}$ & $5.6^{* *}$ & 2.1 \\
\hline \multicolumn{8}{|c|}{ Ventral view } \\
\hline & WM & SJN & RG & CG & SO & MA & SM \\
\hline SJN & $8.9 * * *$ & & & & & & \\
\hline RG & 1.1 & $6.1 * * *$ & & & & & \\
\hline $\mathbf{C G}$ & 3.7 & $12.1 * * *$ & $3.4^{* *}$ & & & & \\
\hline SO & $9.4 * * *$ & $13.7^{* * *}$ & $3.7 * * *$ & $8.9^{*}$ & & & \\
\hline MA & 4.2 & $6.8^{*}$ & 1.9 & 3.9 & $8.7 * * *$ & & \\
\hline SM & 3.0 & $7.5^{*}$ & 1.6 & 1.6 & 4.1 & 2.8 & \\
\hline $\mathbf{C M}$ & $4.2^{*}$ & $9.0 * *$ & 2.4 & 3.5 & 6.2 & 4.4 & 1.4 \\
\hline \multicolumn{8}{|c|}{ Lateral view } \\
\hline & WM & SJN & RG & CG & SO & MA & SM \\
\hline SJN & $4.4^{*}$ & & & & & & \\
\hline RG & 1.2 & $2.9 * *$ & & & & & \\
\hline CG & 3.2 & $10.1 * * *$ & $3.3 * *$ & & & & \\
\hline SO & $8.0 * * *$ & $12.3^{* * *}$ & $3.4 * * *$ & $5.3 * * *$ & & & \\
\hline MA & $6.8^{* *}$ & $13.9 * * *$ & $4.5^{* * *}$ & 5.2 & $4.8^{*}$ & & \\
\hline SM & 3.3 & 5.8 & 1.9 & 4.5 & 2.1 & 5.5 & \\
\hline $\mathbf{C M}$ & $5.2 * *$ & $9.8 * * *$ & $3.6^{* *}$ & $2.9^{*}$ & 2.2 & 3.9 & 1.4 \\
\hline
\end{tabular}

For the dorsal view, the first two canonical variate axes (CV1 and CV2) explain 45.9\% (26.6\% and $19.3 \%$, respectively) of the variation in shape among geographic clusters. The projection of individual scores shows an overlap of the clusters, except for cluster SJN, which was completely separated along negative CV1. Cluster MA (topotypes) is discriminated in positive CV1 with a small overlap with the closest cluster CM. The major shape differences associated to the two first axes in this view are represented in Figure 3a. Specimens from cluster SJN showed a slender rostrum, a broader zygomatic (with anteriorly positioned squamosal root), fronto-parietal suture posteriorly positioned and a less inflated braincase. Specimens in cluster MA showed a shorter rostrum, a narrower zygomatic (posterior positioned squamosal root), fronto-parietal suture anteriorly positioned and a more inflated braincase. For the ventral view, the first canonical variate axes explained $48.7 \%$ of the shape variation (CV1: 26.4\%; CV2: 22.3\%). We observed a marked overlap of the geographic clusters, with a clear discrimination of cluster SJN along the positive CV2 (Fig. 3b). Differences in shape for the two main axes for the lateral view are represented in Figure 3c. Cluster SJN specimens 

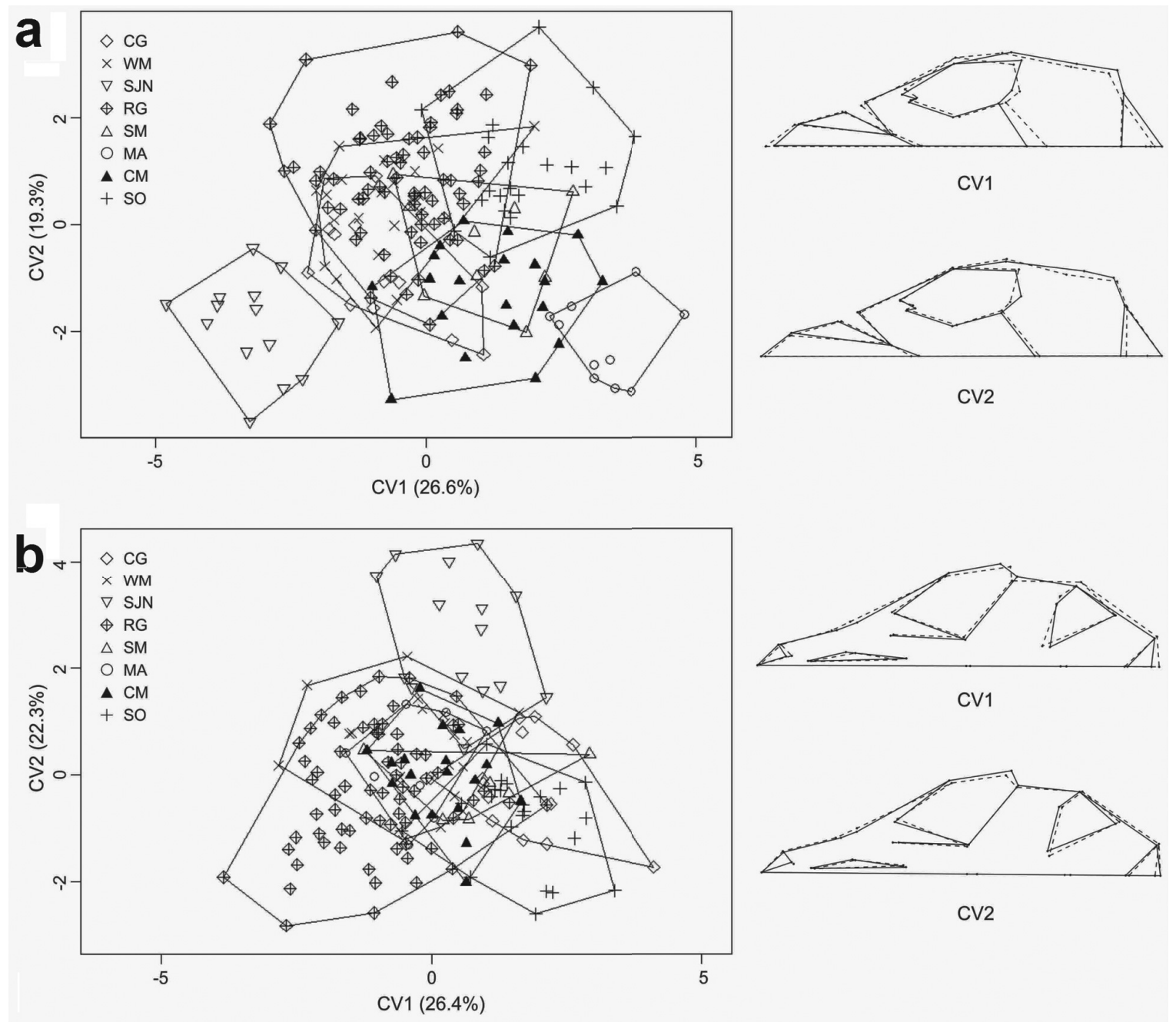

CV1

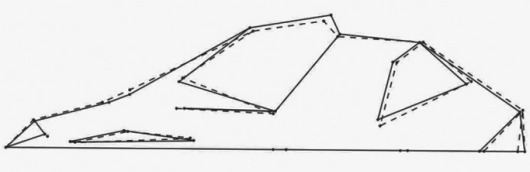

CV2
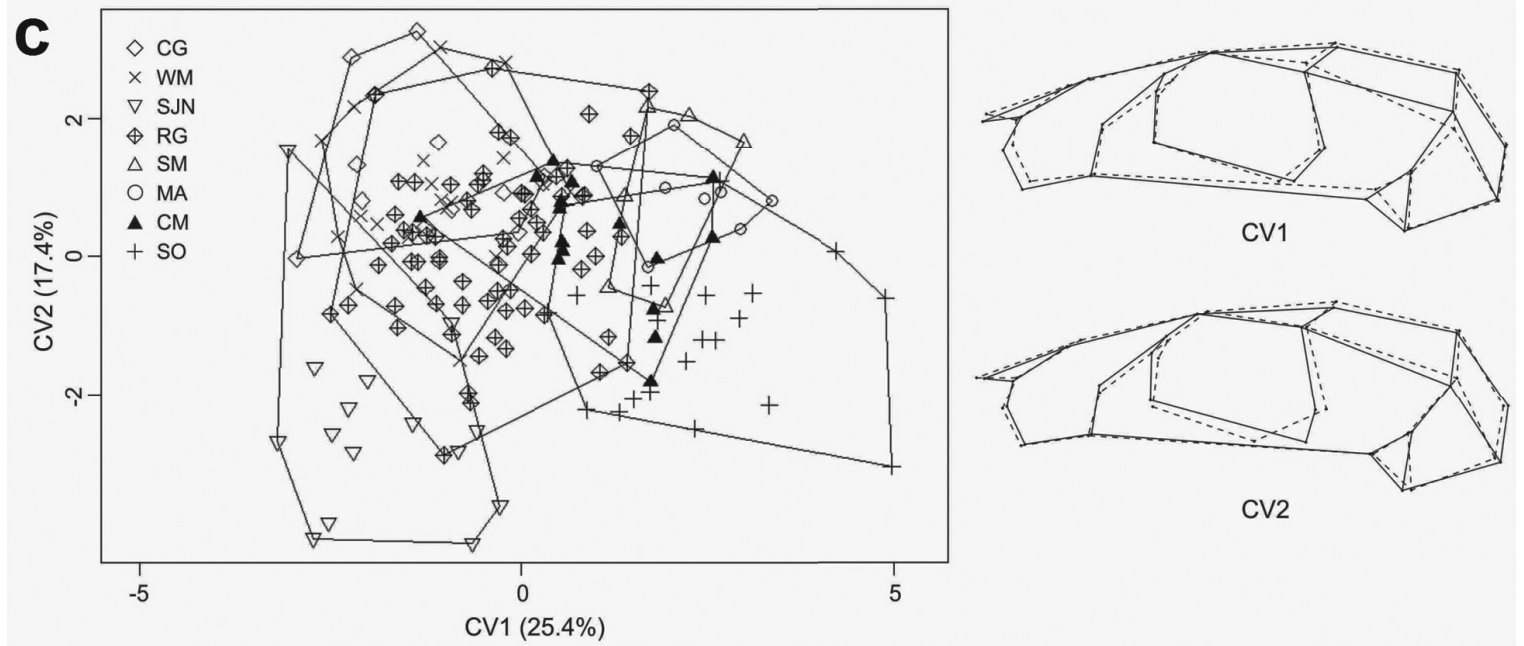

Figure 3 - Scatter plot of two first axes of Canonical Variate Analysis (CVA) for Scapteromys tumidus skull shape configurations of samples from eight geographic clusters in southern Brazil and Uruguay for dorsal (a), ventral (b) and lateral (c) views. CV 1 represent skull shape variation in the first axis and CV 2 represent skull shape variation in the second axis. Positive scores in solid lines and negative scores in dotted lines on the shape difference representations. 
were associated with a posteriorly positioned squamosal zygomatic root and slightly anterior tympanic bulla. In lateral view, the first two CV axes explain $42.8 \%$ of the shape variation (CV1: 25.4\%; CV2: 17.4\%). The cluster SJN sample was discriminated on the negative CV1, while the Uruguayan clusters SO, MA and SM grouped on the positive CV1. Cluster SJN specimens tended to an anteriorly extended premaxillary, posterior squamosal zygomatic root, and broader braincase and tympanic bulla. The Uruguayan clusters on the positive CV1 tended to a shorter anterior premaxillary region, anterior squamosal zygomatic root, and less robust braincase and tympanic bulla.

The percentages of correct classification for each view of the skull are shown in Table II. Considering the mean for the three views, cluster SJN showed the highest percentage of correct classification (91.1\%), while cluster WM showed the lowest percentage value $(60.7 \%)$.

TABLE II

Percentage of correct classification from discriminant analysis for Scapteromys tumidus skull shape from eight geographic clusters in southern Brazil and Uruguay.

\begin{tabular}{ccccccccc}
\hline & WM & SJN & RG & CG & SO & MA & SM & CM \\
\hline Dorsal & 63.6 & 100 & 87.1 & 92.3 & 95.4 & 90.0 & 77.8 & 70.0 \\
Ventral & 45.0 & 80.0 & 82.6 & 76.9 & 81.8 & 37.5 & 66.7 & 47.3 \\
Lateral & 73.7 & 93.3 & 86.9 & 61.5 & 80.9 & 100 & 83.3 & 75.0 \\
\hline
\end{tabular}

The Mantel's test showed significant correlation between the morphological and geographic matrices for the dorsal $(R=0.55, P=0.011)$, ventral $(R=0.51, P=0.015)$, and lateral $(R=0.47$, $P=0.021)$ views of the skull. These results suggest that there are regular and significant associations between skull shape and linear geographical distances among the groups. For the dorsal view, the greatest Mahalanobis distance was found between clusters SJN (middle Rio Grande do Sul coastal plain) and MA (Maldonado; type locality) (Fig. 4a). The phenogram topology showed a clear division of two groups, one formed by the Uruguayan cluster branches and the other formed by the Rio Grande do Sul clusters branches. For the ventral view, the greatest Mahalanobis distance was found between clusters SJN and SO (Fig. 4b). The phenogram topology did not show the geographic structure recovered from the dorsal view, with some Uruguayan and Rio Grande do Sul cluster branches in intercalated positions. For the lateral view, the greatest Mahalanobis distance was also found between clusters SJN and MA
(Fig. 4c). In addition, the phenogram showed the topology of a division in two groups, one formed by the Uruguayan (South) and another formed by the Rio Grande do Sul (North) cluster branches, but with differences in the relative positions of some clusters in relation to dorsal phenogram.

\section{DISCUSSION}

We found marked geographic variation in shape of the water rat Scapteromys tumidus skull. The Mantel's test showed a significant and regular correlation between the geographic and morphological distances, which corroborates with the isolation-by-distance model. This model for population genetics predicts that the gene flow is inversely related to the increase in geographic distances, enhancing the genetic divergence between "subgroups" (Wright 1943). Interpopulational variation in skull morphology correlated with geographic distance has been found previously in echimyid (dos Reis et al. 2002a, b) and murid (Fadda and Corti 1998, 2000, Yazdi et al. 2011) rodents. 

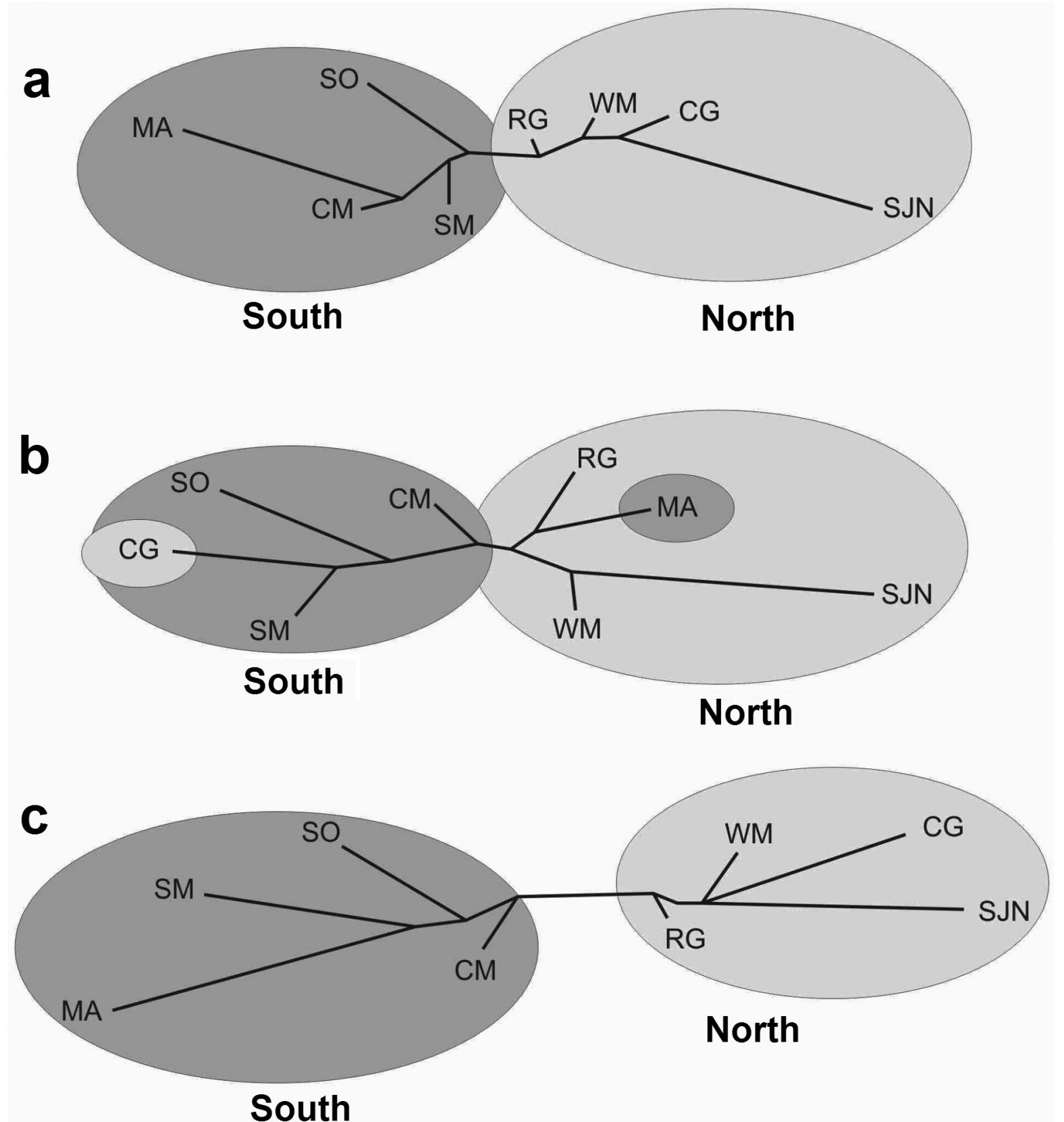

Figure 4 - Neighbor-joining phenograms generated from Mahalanobis distances for dorsal (a), ventral (b) and lateral (c) views of the skull of Scapteromys tumidus. Acronyms correspond to geographic clusters.

The phenogram generated from the dorsal view data (the most informative on geographic variation) showed spatially structured morphological relationships, where the greatest distance was between the central Rio Grande do Sul Coastal Plain samples (cluster SJN) and the topotypes from Maldonado, Uruguay (cluster MA), in the far northeast and extreme southern parts of the species' range, respectively. This geographical structure was also recovered from the lateral view data. Since geographic distances limit dispersal, the rate of migration is higher between nearby populations than between distant populations (Wright 1943, Bradburd et al. 2013). This pattern 
was corroborated by our data from the dorsal and lateral views, where the small morphological distances were found between nearby localities.

The segregation of cluster SJN from all other clusters in the canonical analysis for the dorsal view data is noticeable, indicating a higher differentiation of these populations. Mitochondrial DNA data revealed that $S$. aquaticus and $S$. tumidus are reciprocally monophyletic sister species (D'Elía and Pardiñas 2004, D'Elía 2003, Quintela et al. 2014). Such information, associated with an analysis of the present-day distribution of both species, leads to the hypothesis that the divergence between $S$. aquaticus and $S$. tumidus took place along the Lower Uruguay River basin and, according to Freitas et al. (1984), S. tumidus is in the process of colonization eastward of the River Plate. In this context, S. tumidus populations from Rio Grande do Sul central coastal plain, far from the species center of origin, resulted from long range dispersal events, and may have experienced a morphological differentiation due to reduced gene flow and genetic drift. According to Wright (1943), in "long range populations" or "subdivisions", there is a tendency to the fixation of determined alleles, so that the differentiation within subdivisions is little, whereas the differentiation between subdivisions is marked, drawing a pattern of "local differentiations" resulted from the fixation of different alleles among populations. Additionally, in long dispersal populations, the fixation of exclusive mutant alleles also enhances the local differentiation (Wright 1943). Therefore, it is possible that fixed alleles unique to central Rio Grande do Sul state coastal plain populations have enhanced the morphological differentiation. Nevertheless, because the morphological and geographic distances were not strongly correlated, it is expected that other factors are also associated with the geographic variation in $S$. tumidus skull shape. In addition to the geographic distance, the existence of possible geographic barriers can also hamper the gene flow (Fernandes et al. 2009, Fornel et al. 2010). The spatial heterogeneity over the area covered by the study should also be borne in mind, seeing that the samples of $S$. tumidus used for the analysis came from different palustrine physiognomies (e.g. herbaceous swamps, arbustive swamps, peat and riparian restinga forests, river and stream floodplains).

The skull structure is presumably under high environmental pressure, because it is related to feeding and sensitive functions (Voss et al. 1990). In heterogeneous landscapes, the genetic responses of populations occur directly, via selective processes, or indirectly, via demographic (effective sizes, subdivisions) and stochastic events. These responses produce the genetic variation in species (Pamilo 1988). Subsequent phenotypic variation among populations results from selection and genetic variation, in addition to phenotypic plasticity (Adkinson 1995). Phenotypic plasticity occurs when, under distinct environmental conditions, more than one phenotype is expressed from the same genotype (Pigliucci 2001). This last factor, therefore, is also associated with spatial heterogeneity. Skull morphological differentiation in the murids Gerbillus (Dipodillus) (Abiadh et al. 2010), Mastomys (Lalis et al. 2009), and Taterillus (Dobigny et al. 2002), in the ctenomyid Ctenomys minutus (Fornel et al. 2010) and in the Japanese shrew-mole Urotrichus talpoides (Wilson 2013) were attributed, among other factors, to environmental heterogeneity. An analysis of the shape configurations (Fig. 3) showed that variable structures in S. tumidus skull comprise the zygomatic arch, the squamosal root of zygomatic and the braincase. The zygomatic arch is the site of attachment of some of the masticatory muscles (mandibular adductors): the masseter complex is connected along the maxillary root and median section of the arch; the anterior part of the zygomatic-mandibularis is attached to the maxillary root, while the posterior part of this complex is 
connected from the squamosal root to the glenoid fossa. Another muscle complex involved in mastication is the temporalis. The anterior and posterior temporalis are large muscles attached to the lateral braincase and mandible coronoid process, with the anterior temporalis passing through the posterior orbital fossa (Voss 1988). The regions visually variable in S. tumidus skull, however, are associated to attachment of the muscles involved in the process of mastication. Thus, associated to isolation-bydistance effects, it is possible that local variations on components of the habitat and natural history (e.g. type of soil, feeding habits) may also have led to skull differentiation in S. tumidus. The effect of this and other ecological variables associated to the environmental heterogeneity, however, must be properly tested for a better clarification.

Geographic barriers are known to play an essential role in rodent genetic and morphological differentiation (Colombi et al. 2010, Nascimento et al. 2013). The populations analyzed in the present study are distributed in areas that are part of Precambrian to Holocene geological formations (Bossi and Navarro 1988, Philipp et al. 2000, Tomazelli and Villwock 2000). This range includes several different hydrographic elements: rivers flow into rifts of Precambrian granitic plutons; groundwater upwelling and rainfall excavated the sediments in wind-dispersed mantles of the Holocene coastal plain, which originated coastal streams of varied width; events of marine transgression-regression associated with Pleistocene glaciations and deglaciations resulted in depositional barriers during the maximum marine transgressions, which isolated the PatosMirim lagunar system, the largest lagunar complex in South America (Vieira 1983, 1984, Philipp et al. 2000, Tomazelli and Villwock 2000). The role of water bodies as potential geographic barriers for small mammals is much discussed (see Silva and Patton 1998, Cáceres 2007, Colombi et al. 2010, Fornel et al. 2010, Nascimento et al. 2013), especially considering species with some degree of adaptation to aquatic habits, as is the case of $S$. tumidus (Sierra de Soriano 1969). In view of the discrimination of the cluster SJN samples, it is conceivable that the Patos-Mirim lagunar system (specifically the Patos lagoon estuary, São Gonçalo channel and Mirim lagoon) may form physical barriers to gene flow among populations from both margins. The prevalence of comparatively high $\mathrm{F}$ values between pairs including cluster $\mathrm{SJN}$ in the pairwise MANOVA analysis is also noteworthy. Based on these dissimilarities, samples from the central Rio Grande do Sul Coastal Plain may comprise a distinct geographic morphological unit. To clarify whether this morphological discontinuity is incongruous with $S$. tumidus as a single taxonomic unit, complementary data such as molecular analysis are needed. These analysis are highly recommended, in view of the marked differences between the cluster SJN samples and the topotypes (cluster MA) in dorsal and lateral views, as well as the phenogram distances discussed above.

\section{ACKNOWLEDGMENTS}

We thank Eileen Westwig and Robert S. Voss from the American Museum of Natural History; Eduardo Coelho and Alexandre U. Christoff from the Museu de Ciências Naturais of Universidade Luterana do Brasil; Eduardo Coelho and Tatiane N. S. Fornel for map drawing; Janet Reid for English review and the Instituto Chico Mendes de Conservação da Biodiversidade (ICM-Bio) for granting permission for collection. This research was supported by the Coordenação de Aperfeiçoamento Pessoal de Nível Superior (CAPES), Fundação de Amparo a Pesquisa do Estado do Rio Grande do Sul (FAPERGS) and Conselho Nacional de Desenvolvimento Científico e Tecnológico (CNPq).

\section{RESUMO}

A variação geográfica no tamanho e forma do crânio do rato-do-pântano Scapteromys tumidus foi examinada em amostras de oito clusters geográficos, abrangendo a 
maior parte da distribuição no sul do Brasil e no Uruguai, usamos dois métodos de geometria morfométrica bidimensional para as vistas dorsal, ventral e lateral do crânio. Os descritores geométricos não mostraram diferenças significativas no tamanho do crânio entre os clusters geográficos, enquanto que as diferenças na forma foram altamente significativas. Encontramos correlação significativa e moderada entre distâncias geográficas e morfológicas, corroborando o modelo de isolamento-por-distância. Amostras da planície costeira central do Rio Grande do Sul foram as mais diferenciadas, segregando completamente de todas as outras amostras na análise de variáveis canônicas para a vista dorsal. As regiões visivelmente mais variáveis no crânio foram o arco zigomático (principalmente a raiz esquamosal do zigomático) e as bordas laterais da caixa craniana. Uma vez que a correlação entre as distâncias geográfica e morfológica não foi alta, é possível que outros fatores (heterogeneidade ambiental e/ou barreiras geográficas) venham atuando na diferenciação do crânio de $S$. tumidus.

Palavras-chave: Akodontini, isolamento-por-distância, morfometria geométrica, morfologia craniana, Pampa.

\section{REFERENCES}

Abiadh A, Colangelo P, CANPanna E AND LAMineCHENITI T. 2010. Morphometric analysis of six Gerbillus species (Rodentia, Gerbillinae) from Tunisia. Comp Rend Biol 333: 680-687.

ADAMS DC, ROHLF FJ AND SLICE DE. 2004. Geometric Morphometrics: ten years of progress following the 'revolution'. Ital J Zool 71: 5-16.

ADKISON MD. 1995. Population differentiation in Pacific salmons: local adaptation, genetic drifts, or the environment? Can J Fish Aquat Sci 52: 2762-2777.

AVISE JC. 2000. Phylogeography: the history and formation of species. Cambridge, Harvard University, 447 p.

BARČIOVÁ L. 2009. Advances in insectivore and rodent systematics due to geometric morphometrics. Mammal Rev 39: 80-91.

BARČIOVÁ L AND MACHOLÁN M. 2006. Morphometric study of two species of wood mice Apodemus sylvaticus and A. flavicollis (Rodentia: Muridae): traditional and geometric morphometric approach. Acta Theriol 51: 15-27.

BARLOW JC. 1969. Observations on the biology of rodents in Uruguay. Life Sci Contribut Royal Ontario Mus 75: 1-59.

BAYLAC M. 2008. Rmorph: a R geometric and multivariate morphometrics library. Available from the author: baylac@ mnhn.fr.
BAYLAC M AND FRIESS M. 2005. Fourier descriptors, Procrustes superimposition and data dimensionality: an example of cranial shape analysis in modern human populations. In: Slice DE (Ed), Modern morphometrics in physical anthropology. Springer-Verlag, New York, p. 145-162.

BEOLCHINI F AND CORTI M. 2004. The taxonomy of the genus Tachyoryctes: a geometric morphometric approach. Ital J Zool 71: 35-43.

BONVICINO CR, FERNANDES FA, VIANA MC, TEIXEIRA BR AND D'ANDREA PS. 2013. Scapteromys aquaticus (Rodentia: Sigmodontinae) in Brazil with comments on karyotype and phylogenetics relationships. Zoologia 30: 242-247.

BOOKSTEIN FL. 1991. Morphometric tools for landmark data: geometry and biology. London, Cambridge University Press, $435 \mathrm{p}$.

Bossi J AND NAVARRo R. 1988. Geologia del Uruguay. Universidad de la Republica, Montevideo.

BRADBURD GS, RALPH PL AND COOP GM. 2013. Disentangling the effects of geographic and ecological isolation on genetic differentiation. Evolution 67: 3258-3273.

BRUM-ZORRILLA N, LAFUENTE N AND KIBLISKY P. 1972. Cytogenetics studies in the cricetid rodent Scapteromys tumidus (Rodentia-Cricetidae). Specialia 28: 1373.

BrUm-Zorrilla N, OLIVER G, Gentile DE FronZA T AND WAINBERG R. 1986. Karyological studies of SouthAmerican rodents (Rodentia, Cricetidae). 1. Comparative chromosomic analysis in Scapteromys taxa. Caryologia 39: 131-142.

CÁCERES NC. 2007. Semideciduous Atlantic Forest mammals and the role of the Paraná River as a riverine barrier. Neotrop Biol Conserv 2: 84-89.

COLOMBI VH, LOPES SR AND FAGUNDES V. 2010. Testing the Rio Doce as a riverine barrier in shaping the Atlantic rainforest population divergence in the rodent Akodon cursor. Genet Mol Biol 33: 785-789.

D’ELÍA G. 2003. Phylogenetics of Sigmodontinae (Rodentia, Muroidea, Cricetidae), with special reference to the akodont group, and with additional comments on historical biogeography. Cladistics 19: 307-323.

D'Elía G AND PARDiñas UFJ. 2004. Systematics of Argentinean, Paraguayan, and Uruguayan swamp rats of the genus Scapteromys (Rodentia, Cricetidae, Sigmodontinae). J Mammal 85: 897-910.

DOBIGNY G, BAYLAC M AND DENYS C. 2002. Geometric morphometrics, neural networks and diagnosis of sibling Taterillus species (Rodentia, Gerbillinae). Biol J Linn Soc 77: 319-327.

DOS REIS SF, DUARTE LC, MONTEIRO LR AND VON ZUBEN FJ. 2002a. Geographic variation in cranial morphology in Thrichomys apereoides (Rodentia: Echimyidae). I. geometric descriptors and patterns of variation in shape. $\mathrm{J}$ Mammal 83: 333-344. 
DOS REIS SF, DUARTE LC, MONTEIRO LR AND VON ZUBEN FJ. 2002b. Geographic variation in cranial morphology in Thrichomys apereoides (Rodentia: Echimyidae). II. geographic units, morphological discontinuities, and sampling gaps. J Mammal 83: 345-353.

DRAY S AND DUfOUR AB. 2007. The ade4 package: Implementing the duality diagram for ecologists. J Stat Softw 22: 1-20.

DRYDEN IL AND MARDIA KV. 1998. Statistical shape analysis. J Wiley \& Sons, Inc., New York, 347 p.

ELLERMAN JR. 1941. The families and genera of living rodents. Vol. 2, Family Muridae. London, British Museum of Natural History, $690 \mathrm{p}$.

ERSTS PJ. 2009. Geographic Distance Matrix Generator (version 1.2.3). American Museum of Natural History, Center for Biodiversity and Conservation. http:// biodiversityinformatics.amnh.org/open_source/gdmg. Accessed on June 24, 2012.

FADDA C AND CORTI M. 1998. Geographic variation of Arvicanthis (Rodentia, Muridae) in the Nile Valley. Zeitschriftfür Säugetierkunde 63: 104-113.

FADDA C AND CORTI M. 2000. Three dimensional geometric morphometric study of the Ethiopian MyomysStenocephalemys complex (Murinae, Rodentia). Hystrix 11: 131-144.

FADDA C AND CORTI M. 2001. Three-dimensional geometric morphometrics of Arvicanthis: implications for systematics and taxonomy. J Zool Syst Evol Res 39: 235-245.

FERNANDES FA, FORNEL R, CORDEIRO-ESTRELA P AND FREITAS TRO. 2009. Intra- and interspecific skull variation in two sister species of the subterranean rodent genus Ctenomys (Rodentia, Ctenomyidae): coupling geometric morphometrics and chromosomal polymorphism. Zool J Linn Soc 155: 220-237.

FORNEL R, CORDEIRO-ESTRELA P AND FREITAS TRO. 2010. Skull shape and size variation in Ctenomys minutus (Rodentia: Ctenomyidae) in geographical, chromosomal polymorphism, and environmental contexts. Biol J Linn Soc 101: 705-720.

FreitAs TRO, MATTEVI M AND OLIVEIRA LFB. 1984. Unusual C-band in three karyotypically rearranged forms of Scapteromys (Rodentia, Cricetidae) from Brazil. Cytogenet Genome Res 38:39-44.

FruCiANO C, TIGANO C AND FERRITO V. 2011. Traditional and geometric morphometrics detect morphological variation of lower pharyngeal jaw in Coris julis (Teleostei, Labridae). Ital J Zool 78: 320-327.

Gyldenstolpe N. 1932. A new Scapteromys from Chaco Austral, Argentine. Ark Zool 24: 1-2.

HERSHKOVITZ P. 1966. South American swamp and fossorial rats of the Scapteromyine group (Cricetidae, Muridae), with coments on the glans penis in murid taxonomy. Zeitschriftfür Säugetierkund 31: 81-149.

LALIS A, EVIN A AND DENYS C. 2009. Morphological identification of sibling species: the case of West African
Mastomys (Rodentia: Muridae) in sympatry. Comp Rend Biol 332: 480-488.

MASSOIA E AND FORNES A. 1964. Notas sobre el genero Scapteromys (Rodentia-Cricetidae). I. Sistemática, distribución geográfica y rasgos etoecológicos de Scapteromys tumidus (Waterhouse). Physis 24: 279-297.

Monteiro LR AND Dos ReIS SF. 1999. Princípios de Morfometria Geométrica. Ribeirão Preto, Holos, 188 p.

MULLIN SK, PILLAY N AND TAYLOR PJ. 2004a. Cranial variation and geographic patterns within the Dasymys rufulus complex (Rodentia: Muridae). J Mammal 85: 911-923.

Mullin SK, TAYloR PJ AND PILlaY N. 2004b. Skull size and shape of Dasymys (Rodentia, Muridae) from subSaharan Africa. Mammalia 68: 185-220.

MUSSER GG AND CARLETON MD. 1993. Family Muridae. In: Wilson DE and Reeder DM (Eds), Mammals species of the world: a taxonomic and geographic reference. Washington, Smithsonian Institution Press, p. 501-756.

NASCIMENTO FF, LAZAR A, MENEZER AN, DURANS AM, MOREIRA JC, SALAZAR-BRAVO J, D'ANDREA PSD AND BONVICINO CR. 2013. The role of historical barriers in the diversification processes in open vegetation formations during the Mioceno/Pliocene using an ancient rodent lineage as a model. PLoS ONE 8: e61924.

PAMILO P. 1988. Genetic variation in heterogeneous environments. Ann Zool Fenn 25: 99-106.

PARAdis E, Claude J AND STRIMMER K. 2004. APE: Analyses of phylogenetics and evolution in $\mathrm{R}$ language. Bioinformatics 20: 289-290.

PHILIPP RP, NARDI LVS AND BITENCOURT MF. 2000. O Batólito Pelotas no Rio Grande do Sul. In: Holz M et al. (Eds), Geologia do Rio Grande do Sul. CIGO/UFRGS, Porto Alegre, p. 133-160.

PIGLIUCCI M. 2001. Phenotypic plasticity: beyond nature and nurture. Baltimore, The Johns Hopkins University Press, $328 \mathrm{p}$.

QUINTELA FM, GONÇALVES GL, ALTHOFF SL, SBALQUEIRO IJ, Oliveira LFB AND Freitas TRO. 2014. A new species of swamp rat of the genus Scapteromys Waterhouse, 1837 (Rodentia: Sigmodontinae) endemic to Araucaria angustifolia Forest in Southern Brazil. Zootaxa 3811: $207-$ 225.

ROHLF FJ. 2010. TPSDig2, version 2.16. Stony Brook, NY: Department of Ecology and Evolution, State University of New York. http://life.bio.sunysb.edu/morph. Accessed on June 21, 2012.

ROHLF FJ AND MARCUS LF. 1993. A revolution in morphometrics. Trends Ecol Evol 8: 129-132.

ROHLF FJ AND SLICE D. 1990. Extensions of the Procrustes method for the optimal superimposition of landmarks. Syst Zool 39: 40-59.

SHEETS HD. 2001. IMP: CoordGen6f - Coordinate Generation Utility software. Department of Physics, Canisius College, 
2001 Main St. Buffallo, NY 14208. http://www.canisius. edu/ sheets/morphosoft.html. Accessed on August 12, 2012.

SIERRA DE SORIANO B. 1969. Algunos caracteres externos de cricetinos y su relación com el grado de adaptacion a la vida acuatica (Rodentia). Physis 77: 471-486.

SILVA MNF AND PATON JL. 1998. Molecular phylogeography and the evolution and conservation of Amazonian mammals. Mol Ecol 7: 475-486.

TOMAZELLI LJ AND VILLWOCK JA. 2000. O Cenozóico no Rio Grande do Sul: Geologia da Planície Costeira. In: Holz $\mathrm{M}$ et al. (Eds), Geologia do Rio Grande do Sul. CIGO/ UFRGS, Porto Alegre, p. 375-406.

VENABLES WN AND RIPLEY BD. 2002. Modern Applied Statistics with S. New York, Springer, 495 p.

VIEIRA EF. 1983. Rio Grande: geografia física, humana e econômica. Porto Alegre, Sagra, 158 p.

VIEIRA EF. 1984. Rio Grande do Sul: geografia física e vegetação. Porto Alegre, 184 p.
VOSS RS. 1988. Systematics and ecology of ichthyomyine rodents (Muroidea): Patterns of morphological evolution in a small adaptative radiation. Bull Am Mus Nat Hist 188: 260-493.

Voss RS, MARCUS LF AND ESCALANTE P. 1990. Morphological evolution in muroid rodents I. Conservative patterns of craniometric covariance and their ontogenetic basis in the neotropical genus Zygodontomys. Evolution 44: 1568-1587.

YAZDI FT, ADRIAENS D AND DARVISH J. 2011. Geographic pattern of cranial differentiation in the Asian Midday Jird Meriones meridianus (Rodentia: Muridae: Gerbilinae) and its taxonomic implications. J Zool Syst Evol Res 50: 157164.

WILSON LAB. 2013. Geographic variation in the greater Japanese shrew-mole, Urotrichus talpoides: Combining morphological and chromosomal patterns. Mammal Biol 78: $267-275$.

WRIGHT S. 1943. Isolation by distance. Genetics 28: 114-138.

\section{APPENDICES}

APPENDIX I

SPECIMENS OF Scapteromys tumidus EXAMINED

\begin{tabular}{|c|c|c|c|}
\hline Cluster & Country & Departament/Locality & Sex and collection number \\
\hline $\mathrm{CG}$ & Brazil & $\begin{array}{l}\text { Rio Grande do Sul, Dom Pedrito, Fazenda São } \\
\text { Demétrio }\end{array}$ & $\begin{array}{l}\text { M: MCNU1989, 1990, } 1992 \text { - 1994, } 1998 \text { - } 2003 \text { F: } \\
\text { MCNU1997, } 2004\end{array}$ \\
\hline SJN & Brazil & Rio Grande do Sul, São José do Norte, Bujuru & $\begin{array}{l}\text { M: MCNU3371, } 3374 \text { F: MCNU3370, 3372, 3373, } \\
3375\end{array}$ \\
\hline SJN & Brazil & $\begin{array}{l}\text { Rio Grande do Sul, São José do Norte, km } 14 \text { BR } \\
101 \text { road }\end{array}$ & $\begin{array}{l}\text { M: MCNU3378, 3379, } 3380 \text { - 3382, } 3385 \mathrm{~F}: \\
\text { MCNU3383, 3388, } 3389\end{array}$ \\
\hline WM & Brazil & Rio Grande do Sul, Arroio Grande & M: MCNU701, 702, 2479 F: MCNU700, 705 \\
\hline WM & Brazil & Rio Grande do Sul, Jaguarão & M: MCNU1954, 2097, 2115 F: MCNU2150, 2151 \\
\hline WM & Brazil & Rio Grande do Sul, Capão do Leão, UFPEL & M: MCNU2991, 3023, 3369 F: MCNU2967 \\
\hline WM & Brazil & Rio Grande do Sul, Pedro Osório & $\begin{array}{l}\text { M: MCNU2961, 2966, } 2972 \text { F: MCNU2960, 2974, } \\
3018 \text { - } 3020\end{array}$ \\
\hline $\mathrm{RG}$ & Brazil & Rio Grande do Sul, Mata da Estrada Velha & $\begin{array}{l}\text { M: MCNU598, 931, 1485, 1486, 1525, } 1781 \text { - } 1783 \text {, } \\
\text { 1787 - } 1792 \text { F: MCNU625, 932, 1785, 1786, } 1794\end{array}$ \\
\hline $\mathrm{RG}$ & Brazil & Rio Grande do Sul, Rio Grande, Quinta & $\begin{array}{l}\text { M: AMNH235431, 235433; F: AMNH235434, } \\
235452\end{array}$ \\
\hline RG & Brazil & Rio Grande do Sul, Rio Grande, Lagoa Verde & $\begin{array}{l}\text { M: MCNU3390 - 3392, 3394, 3396, 3398, 3399, } 3401 \\
\text { - 3403, } 3474 \text { F: MCNU3393, 3395, } 3400\end{array}$ \\
\hline RG & Brazil & $\begin{array}{l}\text { Rio Grande do Sul, Santa Vitória do Palmar, } \\
\text { Lagoa Mangueira }\end{array}$ & $\begin{array}{l}\text { M: MCNU3017, 3022, 2965, 2969, 2975, } 2973 \text { F: } \\
2948\end{array}$ \\
\hline RG & Brazil & $\begin{array}{l}\text { Rio Grande do Sul, Sta. Vitória do Palmar, } \\
\text { Fazenda Josapar }\end{array}$ & $\begin{array}{l}\text { M: MCNU2747, 2754, 2755, 2762 - } 2765 \mathrm{~F}: \\
\text { MCNU2748 - 2753, 2756, 2757, } 3404\end{array}$ \\
\hline RG & Brazil & $\begin{array}{l}\text { Rio Grande do Sul, Sta. Vitória do Palmar, } \\
\text { Fazenda Botafogo }\end{array}$ & $\begin{array}{l}\text { M: MCNU467, 683, 684, 686, 3406, 3408, } 3410 \mathrm{~F} \text { : } \\
\text { MCNU1507, 3407, } 3409\end{array}$ \\
\hline SM & Uruguay & $\begin{array}{l}\text { Treinta y Tres, } 16 \text { kilometers south southwest of } \\
\text { Tacuari River mouth }\end{array}$ & $\begin{array}{l}\text { M: AMNH206314, } 206318 \text { - 206320, 206322, } \\
\text { 206327, 206330 F: AMNH206317, 206328 }\end{array}$ \\
\hline
\end{tabular}




\begin{tabular}{|c|c|c|c|}
\hline Cluster & Country & Departament/Locality & Sex and collection number \\
\hline $\mathrm{SO}$ & Uruguay & Soriano, Cardona, 3 kilometers east of Cardona & $\begin{array}{l}\text { M: AMNH206273 - 206275, 206278, 206282, } \\
\text { 206283, 206288, 206296, 206299, 206300, 206302 F: } \\
\text { AMNH206269, 206272, 206276, 206280, 206285 - } \\
206287,206292,206298,206301,206312\end{array}$ \\
\hline MA & Uruguay & $\begin{array}{l}\text { Maldonado, Punta del Este, } 9 \text { kilometers east } \\
\text { northeast of Punta del Este, Maldonado River } \\
\text { mouth }\end{array}$ & $\begin{array}{l}\text { M: AMNH206244, 206248, 206254, 206256, } 206258 \\
\text { F: AMNH206243, 206247, 206249, 206252, } 206257\end{array}$ \\
\hline $\mathrm{CM}$ & Uruguay & Canelones, Pando, mouth of Del Bagre stream & M: AMNH232501 \\
\hline $\mathrm{CM}$ & Uruguay & Canelones, Pando, mouth of Tropa Vieja Stream & F: AMNH232503 \\
\hline $\mathrm{CM}$ & Uruguay & $\begin{array}{l}\text { Canelones, Kilometer } 36 \text { of Interbalnearia } \\
\text { Highway, East of Montevideo }\end{array}$ & $\begin{array}{l}\text { M: AMNH206220, 206230, 206231, 206233 F: } \\
\text { AMNH206209, 206216, 206218, 206219, } 206221 \text { - } \\
\text { 206223, 206234, 206240 }\end{array}$ \\
\hline $\mathrm{CM}$ & Uruguay & $\begin{array}{l}\text { Montevideo, Santiago Vazquez, } 1 \text { kilometer } \\
\text { southeast of Santiago Vasquez, Santa Lucia River }\end{array}$ & $\begin{array}{l}\text { M: AMNH206259, } 206263 \text { F: AMNH206260 - } \\
\text { 206262, } 206264\end{array}$ \\
\hline
\end{tabular}

\section{APPENDIX II}

DEFINITION OF LANDMARKS FOR DORSAL, VENTRAL AND

LATERAL VIEWS OF THE SKULL OF Scapteromys tumidus (REPRESENTED IN FIG. 2):

Dorsal view: 1. anteriormost point of suture between nasals; 2. anteriormost point of suture between nasal and premaxilla; 3. superiormost point of nasolachrymal capsule; 4 . anteriormost point of zygomatic plate; 5. suture between nasal, premaxilla and frontal; 6 . suture between nasals and frontals; 7. posteriormost margin of maximum constriction of antorbital bridge; 8 . posteriormost point of suture between antorbital bridge (maxillary), lachrymal and frontal; 9. posteriormost margin of antorbital bridge process (lachrymal); 10. superiormost margin of zygomatic arch; 11. anteriormost margin of the maximum constriction of squamosal root of zygomatic arch; 12. margim of maximum constriction of interorbital region (frontal); 13. anteriormost point of anterolateral process of parietal; 14. suture between frontal, squamosal and parietal; 15. suture between frontals and parietals; 16. superiormost point of braincase curvature; 17. superiormost point of suture between parietal and occipital; 18 . suture between parietal, interparietal and occipital; 19. suture between parietals and interparietal; 20. posteriormost point of suture between interparietal and occipital; 21. posteriormost point of occipital margin; 22. midpoint of the linear distance between the landmarks 7 and 11 projected to the zygomatic arch.

Ventral view: 1. anteriormost point of suture between nasals; 2 . superiormost point of incisor alveolus; 3. posteriormost point of incisor alveolus; 4. anteriormost margin of incisive foramen; 5. superiormost point of nasolachrymal capsule; 6. posteriormost point of suture between premaxilla and maxilla; 7 . anteriormost margin of zygomaticplate; 8 . anteriormost margin of the maximum zygomatic plate posterior constriction; 9. anteriormost margin of first molar alveolus; 10. posteriormost margin of incisive foramen; 11. posteriormost margin of third molar; 12 . posteriormost point of suture between palatines; 13. superiormost margin of zygomatic arch; 14. posteriormost margin of the maximum anterior constriction of squamosal root of zygomatic; 15. posteriormost point of suture between squamosal and alisphenoid; 16. anteriormost margin of tympanic bulla (ectotympanic); 17. superiormost margin of tympanic bulla (ectotympanic); 18. posteriormost margin of tympanic bulla (ectotympanic); 19. midpoint of suture between basisphenoid and basiocciptal; 20. anteriormost point of inferior margin of foramen magnum; 21. posteriormost 
margin of occipital condyle; 22. posteriormost point of superior margin of foramen magnum; 23. midpoint of the linear distance between the landmarks 8 and 14 projected to the zygomatic arch.

Lateral view: 1. anteriormost point of nasal; 2. anteriormost point of suture between nasal and premaxilla; 3 . posteriormost point of incisor alveolus; 4. inferiormost point of incisor alveolus; 5. posteriormost point of suture between nasal and premaxilla; 6 . inferiormost point of suture between of premaxilla and maxilla; 7. anteriormost point of zygomatic plate; 8. suture between frontal, antorbital bridge (maxillary) and lachrymal; 9. point of maximum posterior constriction of antorbital bridge; 10 . point of maximum posterior constriction of maxillary root of zygomatic arch; 11. point of maximum anterior constriction of squamosal root of zygomatic arch; 12. suture between frontal, parietal and squamosal; 13. inferiormost point of zygomatic arch; 14. suture between parietal, squamosal and occipital; 15. suture between squamosal, alisphenoid and tympanic bulla; 16. superiormost point of tympanic bulla; 17. posteriormost point of tympanic bulla; 18. superiormost point of suture between frontal and parietal; 19. superiormost point of suture between pariental and interparietal; 20 . posteriormost point of occipital; 21. posteriormost point of occipital condyle; 22. midpoint of the linear distance between landmarks 5 and 18 projected to supraorbital (frontal) margin. 